\title{
Contribution to the study of lysine feeding standards for bacon pigs
}

\author{
J. LOUGNON \\ A.E.C., Service Développement Alimentation Animale, o360o Commentry (France)
}

Four feeds based on barley and soybean meal were compared. Their lysine concentration were: $0.62-0.66-0.7^{8}$ and 0.84 p. I 00 , i.e. $2.0-2.15^{-2.5}$ and $2.7 \mathrm{~g}^{2}$ Lsine / $\mathrm{I}$ ooo digestible Kcalories.

These feeds were offered simultaneously to females and castrated males, either ad libitum or according to a progressive feed restriction plan which varied according to sex (maximum 2.5 $\mathrm{kg} /$ day for males and $2.9 \mathrm{~kg}$ for females).

Restricted feeding led to a decrease in growth rate and to a marked improvement of body composition.

The sex influence appeared above all on the carcass quality.

There was a significant interaction between these two factors. It was due to a larger improvement of body composition in castrated males subjected to restricted feeding. For these animals, the feed restriction was more important than for females.

In ad libitum feeding, the optimal lysine level was inferior or equal to $2.0 \mathrm{~g} / \mathrm{I}$ ooo digestible Kcal during the finishing period. During the growing period it was 2.I 5 for castrated males and 2.5 for females.

With a restricted feeding, Lysine levels of 2.5 and $2.0 \mathrm{~g} / \mathrm{I}$ ooo digestible Kcalories seem to be correct for growing and finishing periods in females and castrated males respectively. These results justify the use of the same lysine feeding standards for the two sexes in relation to the energy level of the ration.

\section{Optimal dietary level of balanced protein after amino acid supplementation in growing pigs between 20 and $50 \mathrm{~kg}$ weight}

\author{
Y. HENRY \\ Station de Recherches sur l'Élevage des Porcs, \\ Centre national de Recherches zootechniques, I.N.R.A., \\ 78350 Jouy-en-Josas (France)
}

An experiment was designed to study the possibility of reducing the dietary protein level in growing pigs between 22 and $52 \mathrm{~kg}$ live weight, after correcting the defiencies in essential amino acids. Six groups of $\mathrm{I}_{2}$ animals each (half females and half castrated males) in individual pens were fed maize-soybean meal diets containing one of the following crude protein levels (I $8.7,17.7$, I 5.5 and I 3.4 p. Ioo air dry diet). At the two lowest protein levels (I 5 and I 3 p. I oo the diets were supplemented with $L_{-}$-lysine, with or without addition of supplementary $\mathbf{L}$-lysine, with or without addition of supplementary $\mathrm{L}_{4}$-tryptophan. The animals were moderately restricted to the same scale of feeding according to live weight and received pelleted diets. They were slaughtered at roo $\mathrm{kg}$ body weight after receiving a common finishing diet beyond $52 \mathrm{~kg}$ live weight.

A positive response to supplementary tryptophan, after addition of lysine (first limiting amino acid), in castrated males like in females, was only found at the level of 13 p. Ioo protein, which appeared to be suboptimal for growth performance. That means that the level of non essential nitrogen is the second limiting factor for growth, after lysine and before tryptophan, in the case of a maize-soybean meal mixture. Lysine supplementation is enough by itself for providing a maximal saving of protein supplement in this type of diet.

I,ysine supplementation in the diet of castrated males allowed to decrease the protein level to $\mathrm{r}_{5} \mathrm{p}$. I $\mathrm{ro}$ in a diet containing $89 \mathrm{p}$. I oo dry matter, corresponding to $45 \mathrm{~g}$ crude protein per Mcal digestible energy. 